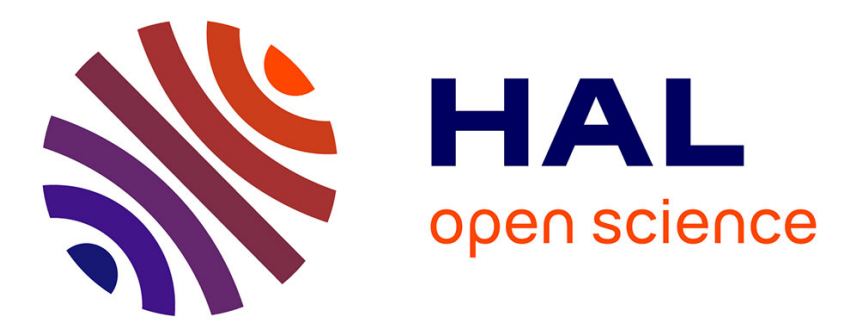

\title{
Boreal trees in the Mediterranean: recruitment of downy birch (Betula alba) at its southern range limit Sanz, Pulido, J. Camarero
}

\section{To cite this version:}

Sanz, Pulido, J. Camarero. Boreal trees in the Mediterranean: recruitment of downy birch (Betula alba) at its southern range limit. Annals of Forest Science, 2011, 68 (4), pp.793-802. 10.1007/s13595011-0076-0 . hal-00930809

\section{HAL Id: hal-00930809 https://hal.science/hal-00930809}

Submitted on 1 Jan 2011

HAL is a multi-disciplinary open access archive for the deposit and dissemination of scientific research documents, whether they are published or not. The documents may come from teaching and research institutions in France or abroad, or from public or private research centers.
L'archive ouverte pluridisciplinaire HAL, est destinée au dépôt et à la diffusion de documents scientifiques de niveau recherche, publiés ou non, émanant des établissements d'enseignement et de recherche français ou étrangers, des laboratoires publics ou privés. 


\title{
Boreal trees in the Mediterranean: recruitment of downy birch (Betula alba) at its southern range limit
}

\author{
Rubén Sanz • Fernando Pulido • J. Julio Camarero
}

Received: 5 October 2010 / Accepted: 22 January 2011 /Published online: 1 June 2011

(C) INRA and Springer Science+Business Media B.V. 2011

\begin{abstract}
- Objective Knowledge of mechanisms determining plant persistence in range edges is essential because peripheral populations face increasing risk and they often maintain unique genotypes.

- Introduction We examined the recruitment limitations, from seed production to seedling establishment, of a boreal tree, the downy birch (Betula alba), in four Spanish relict populations at the southern range limit.

- Materials and methods In 2005 and 2006, seed production and the spatial pattern of seed rain were evaluated. Variability of seed germination was evaluated in a greenhouse, whereas seedling fate was monitored in relation to microhabitat and distance to water sources.

- Results The number of seeds produced was not indicative of source limitation of recruitment. Seed dispersal by wind was primarily a within-stand phenomenon, since $86.4 \%$ of the seeds were trapped under adult birches. Restricted dispersal enhanced the likelihood of reaching safe (moist) microsites in riparian habitats but severely reduced the chances for colonisation of empty suitable habitat patches in adjacent streams. Germination success was uniformly low in all populations (3.6-19.8\%). Ninety-two percent of seedlings emerged at a distance less than
\end{abstract}

Handling Editor: Douglass Jacobs

R. Sanz $\cdot$ F. Pulido $(\bowtie)$

Forest Research Group, School of Forestry,

University of Extremadura,

Avenida Virgen del Puerto 2,

Plasencia E-10600, Spain

e-mail: nando@unex.es

\section{J. J. Camarero}

ARAID-Instituto Pirenaico de Ecología, CSIC,

Avenida Montañana 1005,

Zaragoza E-50192, Spain
$5 \mathrm{~m}$ from the stream, but $93.1 \%$ died because of desiccation during the first summer drought.

- Conclusion It can be concluded that spatially restricted emergence and drought sensitivity occurred in all study populations and that riparian habitats in mountain streams can be considered as local topographic refuges that could buffer large-scale distribution shifts.

Keywords Abiotic stress $\cdot$ Betula alba $\cdot$ Topographic refuges $\cdot$ Marginal populations $\cdot$ Tree relicts

\section{Introduction}

Mediterranean mountain ecosystems are more vulnerable to climate change than other European ecosystems. Predicted climatic scenarios in Mediterranean mountains show a significant decrease in precipitation and a considerable increase in temperature (McCarthy et al. 2001). In addition, recent simulations on the ability of temperate tree species to respond to climate change predict that species with large range sizes will lose climatically suitable area and that the suitable climate space will shift polewards (Ohlemüller et al. 2006). These predictions, derived from Bioclimate Envelope Models, rely on the assumption that factors other than climate are not influential at the relevant scale (Hampe 2004a). However, predictions concerning range boundaries may not reflect actual species distributions if species are able to find local refuges buffering latitudinal shifts at the eroding edge (Castro et al. 2004; Camarero et al. 2005; Truong et al. 2007; Pulido et al. 2008; Mendoza et al. 2009; Sanz et al. 2009; Otto et al. 2010), or if they are not able to disperse to predicted climatically suitable areas at the leading edge (Svenning and Skov 2007). In the case of eroding edges, where populations are expected to be in 
decline, knowledge of the factors limiting tree recruitment and of the ability to track environmental change through dispersal is essential for understanding the persistence of populations (Hampe and Petit 2005). This is especially relevant for tree species of temperate or boreal origin whose Mediterranean relict populations often harbour unique genotypes (Hampe and Petit 2005). Furthermore, the unique features of such populations (low number of individuals, fragmentation, and isolation) usually imply that specific management measures must be undertaken to ensure their conservation (Castro et al. 2004; Pulido et al. 2008; Mendoza et al. 2009; Sanz et al. 2009).

Here, we examine factors limiting population recruitment of downy birch (Betula alba), a dominant tree species in temperate and boreal forests of Europe, whose abundance decreases southwards (Tutin et al. 1993). Previous studies suggest that this species is in fact sensitive to ongoing climate change since it has recently experienced altitudinal shifts in the northern edge of the range (Truong et al. 2007). Mediterranean populations of the species are located in the southern range limit and they are considered as relict and endangered due to the small population size, isolation in benign environments surrounded by inhospitable landscapes, and a number of anthropogenic hazards. Though central European populations have been intensively studied (Kinnaird 1974; Miles and Kinnaird 1979; Kullman 1986; Skoglund and Verwijst 1989; Holm 1994; Laskurain et al. 2002, 2003; Reyes and Casal 2003), their southern counterparts have not been addressed despite their potential for genetic differentiation and extinction risk.

The general purpose of this study was to integrate the analysis of the different phases of the life cycle of downy birch to detect the main bottlenecks hampering tree recruitment in southern peripheral populations. Specifically, we asked the following questions: (1) which is the magnitude and betweenpopulation variability of seed production and viability? (2) Does the spatial pattern of seed dispersal by wind allow colonisation of empty habitat patches in different sites? (3) Are the patterns of seed rain and seedling establishment spatially concordant in different populations? (4) Does the effect of water limitation in a Mediterranean climate differ among populations? By means of this approach, we seek to elucidate the factors determining population viability and to guide conservation measures specific for southern peripheral populations facing rapid climate change.

\section{Materials and methods}

\subsection{Study species}

Downy birch grows in few remnant populations in the Sistema Central mountain range of the central Iberian
Peninsula, where this species reaches its southern range limit (Castroviejo et al. 1990). It is a monoecious tree, with male and female flowers occurring in separated inflorescences or catkins. The species is wind pollinated and mostly self-incompatible (Atkinson 1992). The nutlets developed in the female catkins are winged and they are dispersed by the wind from August to November.

\subsection{Study sites}

Birch populations studied here were located in the central part of the Sistema Central mountain range, north of Cáceres province, Western Spain $\left(40^{\circ} 15^{\prime} \mathrm{N}, 5^{\circ} 45^{\prime} \mathrm{W}\right.$; Fig. 1). The climate is of a mountain Mediterranean type with cold winters and hot and dry summers, with mean annual precipitation of $1,100 \mathrm{~mm}$. Scattered individuals or small groups (less than 50 trees) of this species occur at $950-1,750 \mathrm{~m}$ above sea level. The dominant vegetation around birch populations is composed by heathers (Erica arborea and Erica australis) and brooms (Genista florida and Cytisus oromediterraneus). In all cases, birch trees grow on north-facing slopes along mountain streams, that is, the species behaves as riparian (Fig. 1). This study was conducted in four populations with a maximum distance of $42 \mathrm{~km}$ between them. From west to east, the studied sites were (name and abbreviation): Honduras (HO), Casas del Monte (CM), Nogaledas (NO), and Regaderas (RE) (Fig. 1). Within the study region, we chose these populations from a complete set of 51 sites including at less one individual tree on the basis of a minimum number of individuals ( $>10$ adult trees; Pulido et al. 2007). The total area of each population was determined by using the minimum convex polygon defined by all the trees present in the stand. To describe the size structure of all populations, we defined the following classes: saplings (individuals more than 1 year old and up to $50 \mathrm{~cm}$ in height), juveniles (non-reproductive trees more than $50 \mathrm{~cm}$ tall), and adults (trees bearing reproductive structures).

\subsection{Seed production}

Tree fecundity was analysed in three of the four populations to evaluate the degree of source limitation (Clark et al. 1999). Between 24 and 37 circular seed traps (plastic glasses $12 \mathrm{~cm}$ in diameter, $14 \mathrm{~cm}$ in depth, and $0.011 \mathrm{~m}^{2}$ in area) were placed on the ground under the canopy of fruiting trees in each population in July 2005. Traps were in operation from this date to the end of 2006. Since a pilot study showed no seed predation by ants or birds in the traps, we did not cover the traps with mesh. The content of traps was collected at biweekly sampling periods from midJuly to mid-December in both study years. In the laboratory, the dry content of the trap was weighted and a 


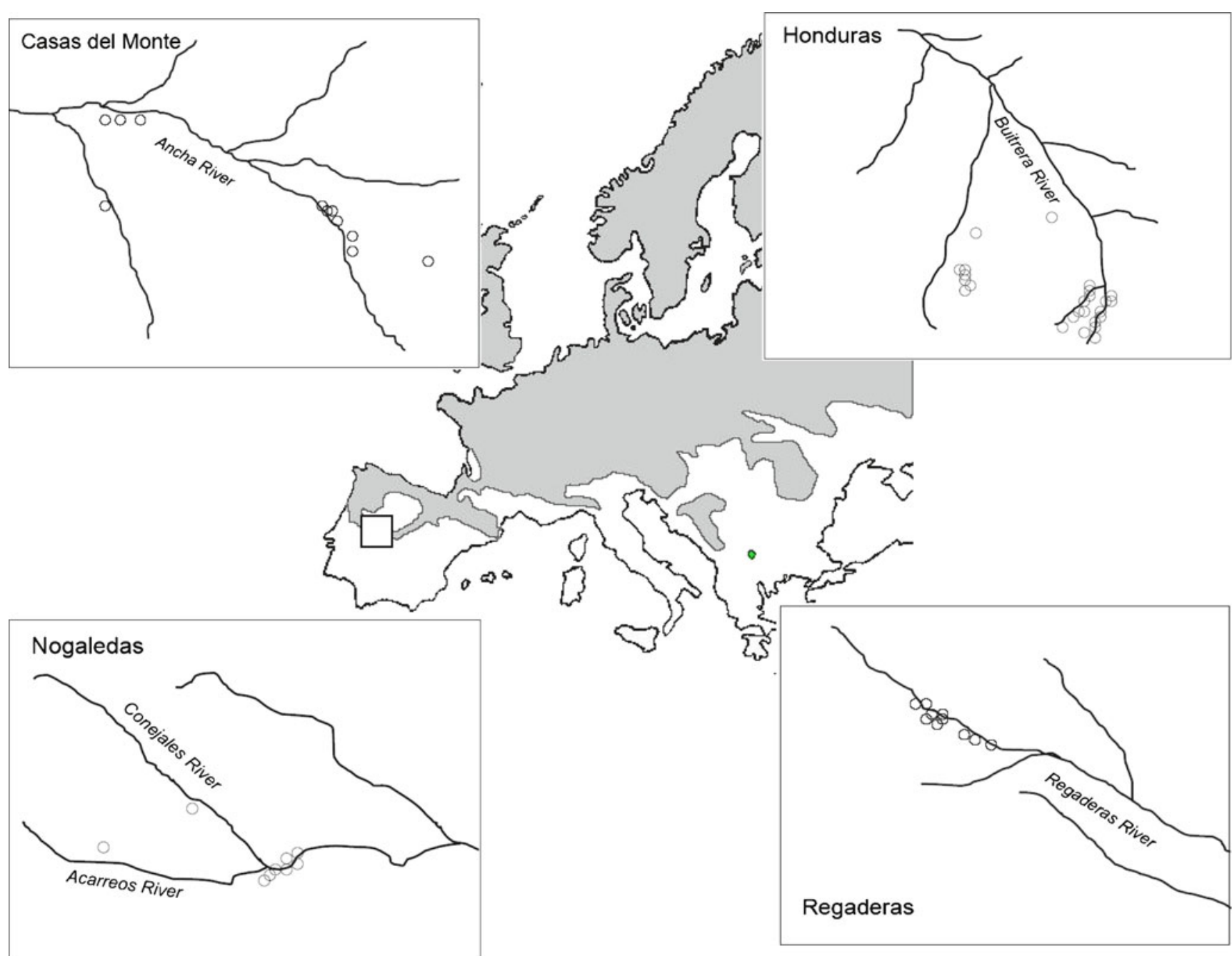

Fig. 1 Maps showing the distribution of downy birch (grey area based on Atkinson 1992 and Svenning and Skov 2007) and the study area (empty square) as well as the spatial arrangement of birch trees within experimental populations (approximate scale 1: 100,000)

1-g sample $(>10 \%$ of the total mass) was extracted to count all the seeds present. The number of seeds fallen in the trap was computed by multiplying the number of seeds in the sample by the total weight of the material collected. When the number of seeds in the trap was low, we counted all of them.

\subsection{Seed viability}

Seed viability was tested in a greenhouse experiment during the first study year (2005). We collected 20 mature catkins from each of five mother trees in each population at the time of fruit dehiscence (mid-October). One hundred seeds from each tree were sown in $40 \times$ $25 \mathrm{~cm}$ plastic trays filled with a $3: 1$ peat-sand mixture. Trays were always well watered (three applications per week) in order to mimic conditions in natural riparian habitats. Seedling emergence was monitored monthly during 1 year from the date of sowing.

\subsection{Seed dispersal}

The strength of dispersal limitation of recruitment was assessed by quantifying the spatial distribution of the seed rain around birch stands in 2005 and 2006. We used the same type of seed traps described above. Traps were placed along four lines with north (from $316^{\circ}$ to $45^{\circ}$ ), east (from $46^{\circ}$ to $135^{\circ}$ ), south (from $136^{\circ}$ to $225^{\circ}$ ), and west (from 226 to $315^{\circ}$ ) orientations. Each line consisted of 12 groups of five traps located at 10, 20, 30, 40, 50, 60, 70, 80, 90, 100, 110, and $120 \mathrm{~m}$ from the centre of the stand. We collected the whole content of traps two times during the dispersal period between late summer and late autumn. The number of seeds fallen in the traps was estimated as described above.

\subsection{Seedling emergence and survival}

We conducted a complete survey of recently emerged seedlings in the four populations in 2005 and 2006. The 
area surveyed was established by using the minimum convex polygon as described above. To detect seedlings emerged outside existing populations, we also searched in 16 transects $(20 \times 5 \mathrm{~m})$, evenly distributed in the left and right margins and in the upstream and downstream of the birch stands. Seedling emergence was inspected three times during June and July, and survival of marked seedlings was checked in November in both study years. For each seedling found, we noted the distance to the nearest stream and the microsite (bare ground, moss, and patches of grass) and microhabitat (beneath birch, alder, fleshy fruited shrubs, and non-fleshy fruited shrubs and open ground) in which the seedling was found. To analyse microhabitat selectivity, we compared the percentage cover of the microhabitats with the percentage of seedlings emerging in them. Cover of microhabitats in each population was estimated by randomly selecting 200 points $(5 \mathrm{~m}$ apart from each other) along parallel transects defined in each stand. On each point, we placed an upright stick and noted the type of microhabitat encountered.

\subsection{Data analysis}

To test for population and year effects on seed production we used general linear models (GLM) on a factorial analysis of variance (ANOVA)-type design. The heterogeneity between populations in germination rates was evaluated by means of GLM with one-way ANOVA design. Pair-wise differences between populations or years were tested with post hoc Fisher's least significant difference (LSD) tests. To test for the effect of population, year, and microhabitat on the density of dispersed seeds, we used GLM on a factorial ANOVA-type design. Generalised linear models (GLZ) and the logit link function were used to test for the effects of cohort, population, microhabitat, and microsite on seedling survival with distance to the nearest stream as a continuous predictor. Survival was considered a dichotomous variable with a binomial distribution. The likelihood ratio was used to evaluate the significance of effects in the model. We used the Statistica package (version 7.0) for all the analyses.

A detailed analysis of the spatial patterns of seed dispersal was conducted by fitting density-distance curves to negative exponential functions for all the orientations, populations, and years. We used Moran's I correlograms to evaluate the spatial pattern in the (log transformed) seed density data of all years, populations, and orientations (Houle 1998; Fortin and Dale 2005). Under the null hypothesis of no spatial autocorrelation, $I$ takes an expected value close to zero, with positive (usually from 0 to +1 ) and negative (usually from 0 to -1 ) values indicating positive and negative spatial autocorrelation, respectively. We calculated $I$ for ten equal-distance classes of $10 \mathrm{~m}$ and each $I$ value was tested for significance. The correlogram was regarded as globally significant if at least one value of $I$ was significant $(P<0.05)$ at the Bonferronicorrected $P^{\prime}=P / k=0.005$, where $k$ is the number of distance classes considered. The distance at which the value of spatial autocorrelation reaches the expected value of no autocorrelation is regarded as the "spatial range" of the studied pattern (Fortin and Dale 2005). All spatial analyses were performed with SAM v. 2.0 (Rangel et al. 2006). Throughout the text means are reported \pm standard deviation.

\section{Results}

\subsection{Size structure}

The four study populations were very small in size, with the number of adult individuals ranging from 11 in NO to 27 in $\mathrm{HO}$ (mean population size 17.25 7.41). These values are higher than the mean $(8.25 \pm 8.77)$ population size in the study region. In general, populations showed an ageing size structure as indicated by their low percentage of saplings or juveniles (recruits). The proportion of recruits was $0.0 \%$ in $\mathrm{RE}, 32.5 \%$ in $\mathrm{HO}$, $26.6 \%$ in NO, and $45.4 \%$ in CM (Fig. 2). Non-adult individuals were mostly juveniles in $\mathrm{NO}$ and $\mathrm{HO}$, while saplings was the only size class occurring in CM.

\subsection{Seed production}

The three populations studied showed considerable differences in tree fecundity as estimated by seed density beneath birch trees. Seed production varied between a maximum of $30,655 \pm 4,223$ seeds $/ \mathrm{m}^{2}$ in $\mathrm{HO}$ in 2005 and a minimum of $6,287 \pm 3,401$ seeds $/ \mathrm{m}^{2}$ in NO in 2006 (Fig. 3). A highly significant effect of population on seed production was noted, while the effect of year was

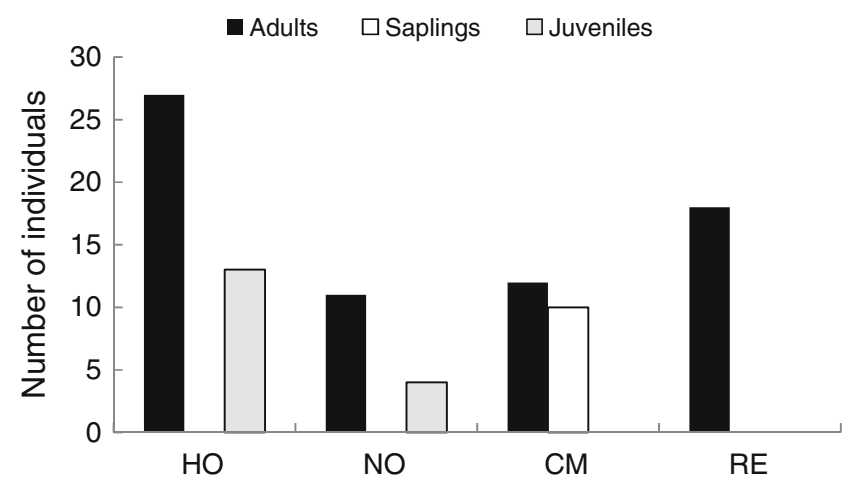

Fig. 2 Frequency of different size classes in the four populations of downy birch studied in central Spain. $H O$ Honduras, $N O$ Nogaledas, $C M$ Casas del Monte, and RE Regaderas 


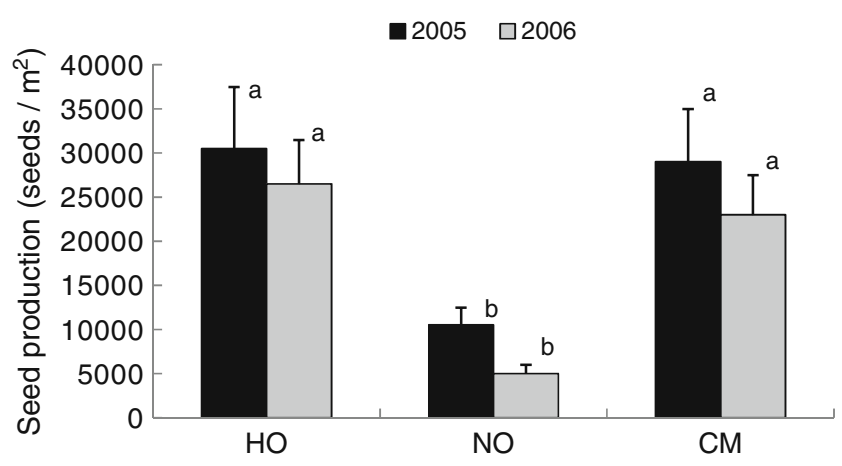

Fig. 3 Seed production in three populations of downy birch in central Spain. Different letters indicate significant $(P<0.05)$ differences between sites for a given year. $H O$ Honduras, $N O$ Nogaledas, $C M$ Casas del Monte

marginally significant due to a decrease in fecundity in 2006 in all populations (Table 1). Seed production was higher in $\mathrm{HO}$ and $\mathrm{CM}$, with $\mathrm{NO}$ showing much lower values. This pattern was consistent among years (Table 1).

\subsection{Spatial pattern of seed dispersal}

This section deals with the whole seed shadow, extending from 0 to $120 \mathrm{~m}$ from the centre of a given stand. Maximum seed densities were observed at the smallest distance from the stand (Table 2). The seed-dispersal curves were leptokurtic in the four orientations and both years, and they were successfully fitted to negative exponential functions (Table 2, Fig. 4). The parameter describing the exponential decay $(b)$ was significantly greater in the year $2006(0.27 \pm 0.02)$ than in $2005(0.18 \pm$ $0.02)$ (ANOVA, $F=9.13, d f=1,22, P=0.007$ ). The correlograms of seed density corresponded to spatial gradients confirming the sharp decrease in seed density at greater distances from the populations (Fig. 5).

The "spatial range" of the seed-density patterns in the year 2005 was ca. $45 \mathrm{~m}$ in most populations and orientations. Note that $90-95 \%$ of all the dispersed seeds per populations were detected from 0 up to $50 \mathrm{~m}$ apart from the studied stand, and this distance corresponds to the levelling of the seed-density values when expressed in a logarithmic scale (Figs. 4, 5). In the year 2006, the spatial correlograms corresponded again to gradients and they

Table 1 Results from general lineal models (factorial ANOVA design) testing for the effects of population and year on seed production in downy birch populations

\begin{tabular}{llrl}
\hline & $d f$ & $F$ & $P$ \\
\hline Population & 2,180 & 16.099 & 0.000 \\
Year & 1,180 & 3.885 & 0.050 \\
Population $\times$ year & 2,180 & 0.233 & 0.792 \\
\hline
\end{tabular}

indicated a smaller "spatial range" of seed dispersal (ca. $35 \mathrm{~m}$ ), especially in NO and CM.

Concerning long-distance dispersal events, on average, only $0.29 \%$ of the seeds trapped were dispersed beyond $100 \mathrm{~m}(0.45 \%$ in $\mathrm{HO}, 0.07 \%$ in $\mathrm{NO}$, and $0.22 \%$ in $\mathrm{CM}$ ). These proportions give a general picture of whether dispersed seeds could reach suitable habitats (springs) close to existing birch populations. The mean distance from each stand to the five nearest streams were $95.3 \pm 18.4 \mathrm{~m}$ in $\mathrm{HO}, 203.8 \pm 97.5 \mathrm{~m}$ in $\mathrm{CM}$, and $153.1 \pm 72.9 \mathrm{~m}$ in NO.

The short-distance dispersal pattern also had consequences for the distribution of seeds delivered to different microhabitats. Over all populations, $86.7 \%$ of the seeds were trapped under birch trees, with few seeds reaching other microhabitats $(8.5 \%$ of seeds were trapped in open ground and $4.7 \%$ in shrubs). A three-way ANOVA with seed density as a dependent variable showed a highly significant effect of year, population, and microhabitat (including birch; Table 3). In addition, all the interactions involving the "microhabitat" factor were significant, indicating a strong spatiotemporal inconsistency in the pattern of seed rain among microhabitats.

\subsection{Seed germination}

Germination rates found in the 2005 experiment were generally low in all populations. Mean values found were $3.6 \%$ in $\mathrm{NO}, 4.6 \%$ in $\mathrm{CM}, 17.8 \%$ in RE, and $19.8 \%$ in HO ( $n=5$ mother trees in each population). A one-way ANOVA showed a highly significant difference between populations $(F=6.491, d f=3,16, P=0.004)$, which could be attributed to differences in the pairs NO-CM and RE-HO as shown by Fisher's LSD tests (results not shown).

\subsection{Seedling emergence and establishment}

Seedling emergence started in mid-June and was completed by mid-July in both study years. There was huge variation among years in the number of seedlings emerged (173 seedlings in 2005 and 431 in 2006; all four populations pooled). As expected from adult and seed distributions, seedling emergence peaked in the vicinity of streams with $92.4 \%$ of seedlings emerging closer than $5 \mathrm{~m}$ from the riverbed. Seedling emergence was disproportionately higher under moist microhabitats, as judged from the difference of percentage seedlings emerged and percentage of microhabitat availability: $48.9 \%$ vs. $2.1 \%$ for birch, $13.3 \%$ vs. $1.1 \%$ for alder, $6.1 \%$ vs. $4.5 \%$ for fleshy fruited shrubs, and $9.9 \%$ vs. $51 \%$ in the open. Concerning distribution among microsites, most of the 605 seedlings found (all years and 
Table 2 Descriptive statistics of seed density and exponential negative curve fits $\left(y=a \times \mathrm{e}^{(-b x)}\right)$ of distance-seed density relationships for the different populations and years

All fits were highly significant $(P<0.001)$

\begin{tabular}{lllllll}
\hline Population & Year & Mean seed density $\left(\mathrm{seed} / \mathrm{m}^{2}\right)$ & $a$ & $b$ & SE & $r$ \\
\hline Honduras & 2005 & $3471 \pm 796$ & $26,345.51$ & 0.17 & 811.55 & 0.994 \\
Nogaledas & 2005 & $1369 \pm 374$ & $13,231.16$ & 0.19 & 362.07 & 0.995 \\
Casas del Monte & 2005 & $2926 \pm 750$ & $31,367.35$ & 0.22 & 308.61 & 0.999 \\
Honduras & 2006 & $1689 \pm 510$ & $17,229.72$ & 0.32 & 107.01 & 0.999 \\
Nogaledas & 2006 & $434 \pm 102$ & $4,844.55$ & 0.22 & 30.57 & 0.999 \\
Casas del Monte & 2006 & $740 \pm 171$ & $8,612.90$ & 0.27 & 62.74 & 0.999 \\
\hline
\end{tabular}

populations pooled) emerged in cushions of mosses $(50.6 \%)$ or bare ground $(43.8 \%)$, whereas few seedlings emerged in patches of grass $(2.6 \%)$ and rocks $(1.5 \%)$. Though we did not estimate microsite availability, these results clearly indicate a preference for mosses and the rejection of herb cover.

Survival rates were very low in all populations in the 2 years. After the first summer, the percentage survival for all populations ranged from $0 \%$ to $1.5 \%$ in 2005 and from $3.9 \%$ to $5.5 \%$ in 2006 . Overall, only $6.9 \%$ of seedlings found in all populations and years were alive after the first summer ( $n=604$ seedlings; Fig. 6). In almost all cases $(92.9 \%)$ seedling mortality occurred during the drought period with no signs of biotic damage (only $0.5 \%$ of seedlings were trampled). GLZ modelling showed highly significant effects of distance to stream and microsite on seedling survival (Table 4). Since these effects were

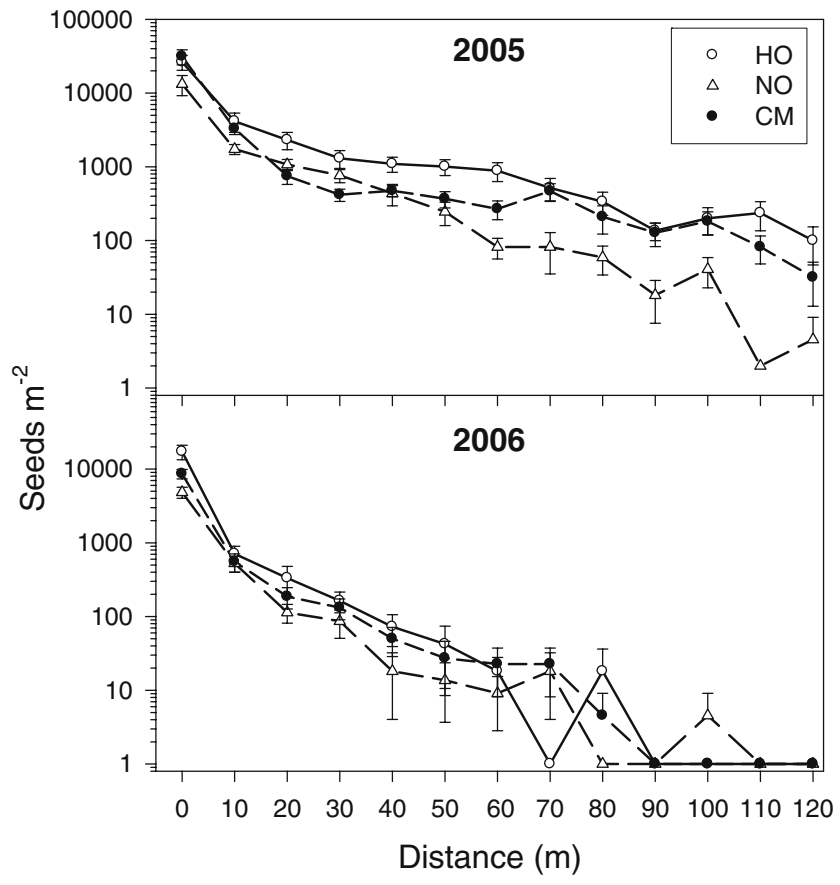

Fig. 4 Variation of seed density with distance in 2005 and 2006 in three downy birch populations of central Spain. Values of seed density at each distance were computed as the mean number of seeds fallen in five traps. Note the logarithmic scale on the vertical axis. $H O$ Honduras, $N O$ Nogaledas, $C M$ Casas del Monte consistent for all populations, we pooled data from all of them to perform within-population analyses. Thus, in all study sites, seedling survival primarily depended on distance to water sources, with no seedlings surviving more than $3 \mathrm{~m}$ apart. Within this distance interval, survival was significantly enhanced in the absence of grass competition, especially in association with mosses. Thus, besides favouring emergence, mosses provided the best site for seedling survival: $6.5 \%$ of seedlings which emerged on moss survived, as compared to $1.1 \%$ of seedlings emerging on bare ground.

\section{Discussion}

\subsection{Demographic structure}

For the downy birch, available information on stand structure shows that marginal populations tend to be isolated and small in size (Kinnaird 1974 and this study). In addition, our study showed a generalised regeneration deficit, as the number of recruits (saplings plus juveniles) was lower than the number of adults in all populations. To our knowledge, this recruitment failure has been only found in our peripheral populations. Nevertheless, clear differences among populations in the total number of recruits and in the proportion of saplings (recent regeneration) versus juveniles (older regeneration) suggest that demographic responses to factors limiting regeneration are site specific and are probably linked to the recent management history. Thus, local topography may have been influencing the impact of livestock grazing with site-specific intensity (Reyes and Casal 2000; Pulido et al. 2007).

4.2 Seed production and viability: magnitude and variation among populations

Seed production showed significant differences between populations and, to a lesser extent, between years. The same was true of populations of Betula alleghaniensis in North America (Houle 1999) or Betula pendula in Sweden (Holm 1994) and Spain (Reyes and Casal 2000). The 
Fig. 5 Moran's I spatial correlograms of seed density for three downy birch populations of central Spain in 2005 and 2006. All correlograms were globally significant $(P<0.05)$. Solid symbols indicate significant coefficient values at $P=0.05$. The circles indicate the "spatial range" of the seed-density patterns, i.e. where the $I$ values cross the axis of $I=0$. Different orientations are denoted by symbols. HO Honduras, $\mathrm{NO}$ Nogaledas, $C M$ Casas del Monte

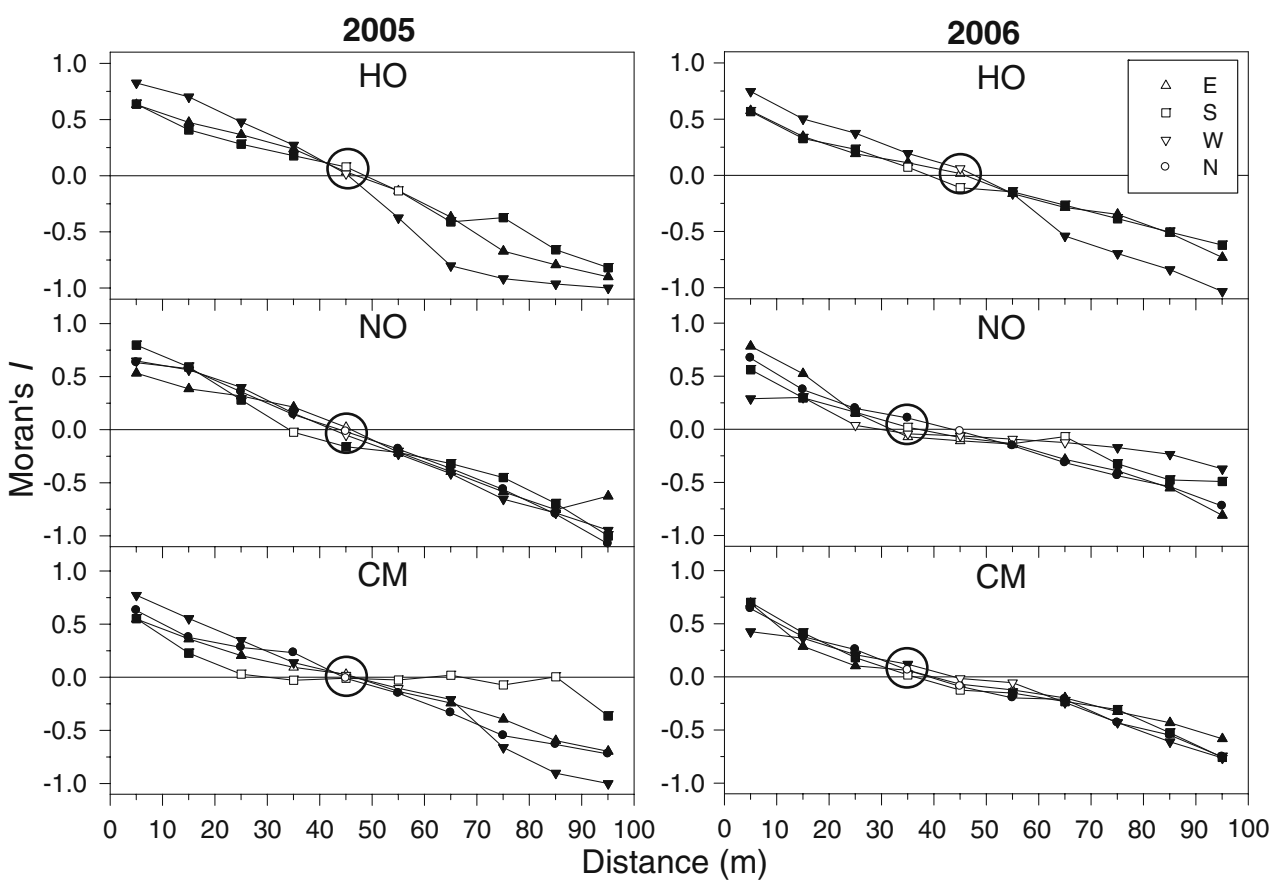

values of tree fecundity found in our populations were in the upper part of the range found in several birch species. Thus, Sarvas (1948) reported a maximum crop of 2,300 seeds $/ \mathrm{m}^{2}$ in B. pendula in Finland. Seed crops between 3,800 and 43.000 seeds $/ \mathrm{m}^{2}$ were recorded in Scotland (Miles and Kinnaird 1979), whereas the range in northern Spain was 28,659-62,739 seeds $/ \mathrm{m}^{2}$ (Reyes and Casal 2003). Overall, we found no evidence of decreased fecundity in our peripheral conditions and it seems very unlikely that regeneration was hampered by tree fecundity or source limitation (Clark et al. 1999).

Germination success in our peripheral populations was very low (4-20\%) as compared to that reported for the core populations from which information is available (Sarvas 1948; Holm 1994; Reyes and Casal 2003). Only Miles and Kinnaird (1979) recorded comparable values (15\%) for Scotland, though our mean values were even lower (11.4\%). As noted by Reyes and Casal (2003), seed

Table 3 Results from general linear models (ANOVA design) testing for the effect of population, year, and microhabitat on the density of seeds dispersed up to $120 \mathrm{~m}$ from the centre of the populations

\begin{tabular}{llrl}
\hline Effect & $d f$ & \multicolumn{1}{l}{$F$} & \multicolumn{1}{l}{$P$} \\
\hline Population & 2 & 14.445 & 0.000 \\
Year & 1 & 41.976 & 0.000 \\
Microhabitat & 4 & 227.539 & 0.000 \\
Population $\times$ year & 2 & 3.065 & 0.047 \\
Population $\times$ microhabitat & 8 & 16.654 & 0.000 \\
Year $\times$ microhabitat & 4 & 37.036 & 0.000 \\
Population $\times$ year $\times$ microhabitat & 8 & 4.926 & 0.000 \\
\hline
\end{tabular}

viability might be related to population structure (via its effects on pollen flux or genetic make-up), as it was lowest in the smallest population (Nogaledas) and highest in the largest one (Honduras). If this is the case, small population size could imply an intrinsically low reproductive efficiency independent of extrinsic environmental conditions. This circumstance could aggravate if we consider that our four study stands were among the largest in the set of 51 populations present in the region.

The limiting role played by germination in birch population recruitment has been discussed by Kullman (1986), who suggested that seed germination was not an important bottleneck in the life cycle of mountain birch (Betula pubescens subsp. tortuosa) because a large seed

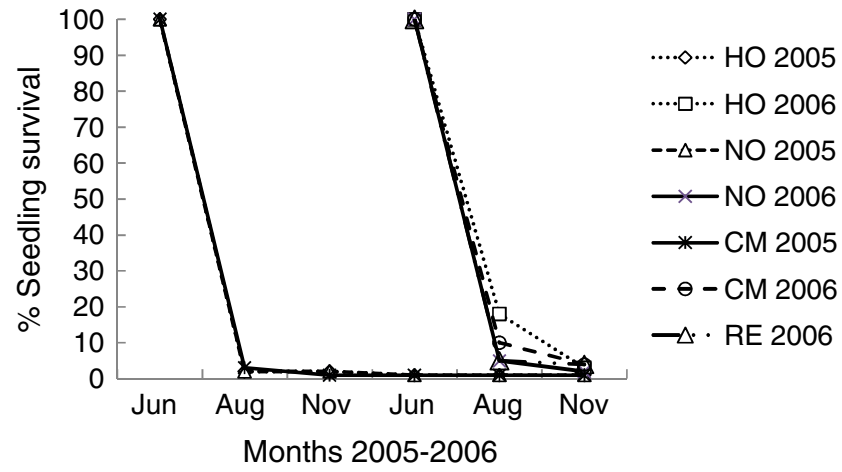

Fig. 6 Cumulative proportion of seedlings surviving in the four populations of downy birch in central Spain during 2005 and 2006. The 2005 cohort was monitored from June 2005 to November 2006, while the 2006 cohort was monitored from June 2006 to November 2006. $H O$ Honduras, $N O$ Nogaledas, $C M$ Casas del Monte, and $R E$ Regaderas 
Table 4 GLZ models testing for the effects of distance to the nearest stream, microsite, microhabitat, cohort, and population on seedling survival

\begin{tabular}{llrr}
\hline Effect & $d f$ & $\chi^{2}$ & $P$ \\
\hline Distance to stream & 1 & 24.902 & $<0.001$ \\
Microsite & 2 & 15.447 & $<0.001$ \\
Microhabitat & 4 & 3.390 & 0.495 \\
Cohort & 1 & 5.249 & 0.022 \\
Population & 3 & 3.100 & 0.376 \\
Cohort $\times$ population & 4 & 1.387 & 0.300 \\
Cohort $\times$ microsite & 3 & 1.935 & 0.586 \\
Cohort $\times$ microhabitat & 2 & 2.881 & 0.237 \\
Population $\times$ microsite & 4 & 6.766 & 0.148 \\
Population $\times$ microhabitat & 2 & 8.611 & 0.135 \\
Cohort $\times$ population $\times$ microsite & 1 & 0.000 & 0.999 \\
Cohort $\times$ population $\times$ microhabitat & 1 & 0.000 & 1.000 \\
Cohort $\times$ population $\times$ microhabitat $\times$ microsite & 1 & 0.000 & 1.000 \\
\hline
\end{tabular}

production could lead to the establishment of a dense seedling bank even with low germination success. This reasoning is valid for sites where there is no microsite limitation and viable seeds cannot saturate available safe sites for seedlings (Clark et al. 1999). In our case, close dependence on watered microsites could make low germination an important bottleneck in the regeneration process (see below).

\subsection{Seed dispersal: the unlikely colonisation of empty} habitat patches

Despite huge differences in the magnitude of the seed rain in different populations and years, the spatial pattern of dispersed seeds was very similar in all of them (see Houle 1998 for a similar result). Secondary seed dispersal through snow (Matlack 1989; Greene and Johnson 1997) or water flow (Hampe 2004b) could also have taken place, though these processes could not greatly modify the primary pattern of seed rain generated by wind. Most seeds $(84.7 \%)$ did not leave their source birch stands and the spatial range of the dispersal process was uniformly small in all populations. On the other hand, a pilot study performed in 2006 in the $\mathrm{HO}$ site revealed that all experimental seeds were leached from the riverbed in trays located along the stream down the birch population. In fact, we did not found any sapling or juvenile tree growing within transects located in the downstream of existing birch stands. Overall, these evidences indicate that effective hydrochory is unlikely in our study system.

In a regional context, the most relevant question related with dispersal is whether seed transport can lead to colonisation of suitable empty sites. Our results were in agreement with previous studies in that almost all seeds were deposited within a radius of $35-45 \mathrm{~m}$ from source trees (Sarvas 1948). Furthermore, in our case, only $6.9 \%$ of the dispersal events occurred beyond $10 \mathrm{~m}$ from existing populations. Whether seed export can lead to the establishment of recruits depends on the probability of reaching suitable microsites in nearby streams, which must generally occur through long-distance $(>100 \mathrm{~m})$ dispersal.

Downy birch nutlets have been reported to disperse more than $400 \mathrm{~m}$ from the mother tree or even more than $1,000 \mathrm{~m}$ (Van der Pijl 1982). Maximum dispersal distances for other birch species are $475 \mathrm{~m}$ in Betula papyrifera (Greene and Johnson 1996), $80 \mathrm{~m}$ in Betula lenta (Matlack 1992), and $300 \mathrm{~m}$ in B. pubescens ssp. tortuosa (Molau and Larsson 2000). Records of the proportion of seeds dispersed more than $100 \mathrm{~m}$ are very scarce (5\% in Betula uber according to Ford et al. 1983 and $0.29 \%$ in our study). On the basis of the amount of seeds dispersed far and the mean distance from populations to nearby streams, we concluded that seed arrival to suitable patches away from those already occupied could be possible (though very unlikely) in one population (Honduras), but it would be virtually unfeasible in the remaining ones. In addition, it must be taken into account that seeds must fall within a narrow belt of moist soil close to streams, which further reduces the probability of seeds landing in suitable microsites. Hence, the ability to colonise potentially suitable streams is strongly constrained by the low number of seeds reaching them, by low seed viability, and by the spatial arrangement of streams within catchments.

4.4 Seedling emergence and survival: a case for strong abiotic constraints

Seedling emergence concentrated in the vicinity of streams, with $92.4 \%$ of seedlings emerging within $5 \mathrm{~m}$ of the riverbed despite what we found that the spatial range of seed rain extended up to 35-45 $\mathrm{m}$. Thus, seed deposition under source birch trees growing in riparian sites would in 
most cases ensure that water supply was sufficient for germination and establishment (see below). Enhanced conditions under birches would stem from the positive role of small, watered sand banks and mosses as a germination seedbed. The facilitative role of mosses for seed germination has been reported in previous studies with B. alba and B. pendula (Kinnaird 1974) and Taxus baccata (Sanz et al. 2009). We suggest that cushions of mosses may buffer moisture fluctuations and provide attachment for dispersed seeds and seedlings.

We found extremely low values of seedling survival after the first summer. This was a common characteristic of our four populations and also of all previous studies on birches across Europe (Kinnaird 1974; Miles and Kinnaird 1979; Kullman 1986; Skoglund and Verwijst 1989; Laskurain et al. 2003). These studies also found frost damage during the first winter to be the second cause of seedling mortality. Thus, available information demonstrates that early survival of seedlings is almost exclusively limited by abiotic factors. This also applies to our marginal populations, where soil moisture during the first summer is critical for survival. Trampling of seedlings by large herbivores, potentially attracted to these mountain streams in summer (Castro et al. 2004; Sanz et al. 2009), has not been noted in our study sites. This could be due to seedling desiccation occurring early in summer prior to the intensive use of riparian habitats by herbivores. In a later stage of the life cycle, conversion of seedlings to woody saplings or juveniles most likely depends on protection from herbivore damage as exemplified by the nurse effects of heaths found by Kinnaird (1974). In close agreement, saplings and juveniles in our populations were always found within dense heath patches (Sanz, unpublished data).

\subsection{Synthesis: recruitment and conservation of southern peripheral populations}

Three main findings can be outlined from this study. Firstly, the number of seeds produced is not suggestive of source limitation. Secondly, rare long-distance dispersal events to suitable empty habitats combined with poor germination and unfavourable landscape configuration might prevent the foundation of new birch populations. Finally, seed dispersal was primarily a within-stand phenomenon, and this short-distance dispersal enhances the likelihood of reaching safe (moist) microsites for seedling emergence and survival. The fact that the main results concerning the different steps of the regeneration process applied to all populations studied suggests that they might be representative for southern marginal populations of birch.

Abiotic constraints influencing seedling survival have been shown to be the main driving force of recruitment in relict populations of several "non-Mediterranean" species under Mediterranean climate (Castro et al. 2004; Pulido et al. 2008; Mendoza et al. 2009; Sanz et al. 2009; Otto et al. 2010). More generally, strong sensitivity of demographic processes to drought stress has been pointed out for many tree species growing under Mediterranean climate (Brèda et al. 2006). In the case of southern peripheral populations of downy birch, strong microsite limitation of recruitment makes this species a strictly riparian one. Thus, midelevation streams can be considered as local refuges buffering distribution shifts such as those found in the northern edge of the species' range (Truong et al. 2007). The suitability of these habitats as local refuges can be predicted to decrease with increased climate warming and subsequent changes in the water regime (Ohlemüller et al. 2006). In this scenario, the conservation of these endangered populations will most probably requires an active management aimed at preserving existing water sources and allowing the foundation of new populations through assisted seed dispersal and seedling protection.

Acknowledgments This study has been made possible by funds from the Consejería de Agricultura y Medio Ambiente of the Junta de Extremadura (project FEA II 2004-2006) and the Spanish Ministry for Education and Science (project BOSALIM-DEMODIS, CGL200766066-C04-01/BOS). We are grateful to O. Reyes, N.A Laskurain, and A. Hampe for making very useful suggestions and to Nicholas Alldred for his linguistic advice. We are also indebted to D. Abel, L. Jiménez, A. Martín, and M. S. Martín for their invaluable help during field work. This work was possible thanks to the GLOBIMED network for the study of Mediterranean Forest Ecosystems.

\section{References}

Atkinson MD (1992) Betula pendula Roth (B. verrucosa Ehrh.) and B. pubescens Ehrh. J Ecol 80:837-870

Brèda N, Huc R, Granier A, Dreyer E (2006) Temperate forest trees and stands under severe drought: a review of ecophysiological responses, adaptation processes and long-term consequences. Ann For Sci 63:625-644

Camarero JJ, Gutiérrez E, Fortin MJ, Ribbens E (2005) Spatial patterns of tree recruitment in a relict population of Pinus uncinata: forest expansion through stratified diffusion. J Biogeogr 32:1979-1992

Castro J, Zamora R, Hódar JA, Gómez JM (2004) Seedling establishment of a boreal tree species (Pinus sylvestris) at its southernmost distribution limit: consequences of being in a marginal Mediterranean habitat. J Ecol 92:266-277

Castroviejo S, Laínz M, López G, Monserrat P, Muñoz F, Paiva J, Villar L (1990) Flora Ibérica: plantas vasculares de la Península Ibérica e Islas Baleares, volume II. Real Jardín Botánico (CSIC), Madrid, $897 \mathrm{pp}$

Clark JS, Beckage B, Camill P, Cleveland B, HillerRisLambers J, Lichter J, McLachlan J, Mohan J, Wyckoff P (1999) Interpreting recruitment limitation in forests. Am J Bot 86:1-16

Ford RH, Sharik TL, Feret PP (1983) Seed dispersal of the endangered Virginia round leaf birch (Betula uber). For Ecol Manag 6:115-128

Fortin M-J, Dale M (2005) Spatial analysis: a guide for ecologists. Cambridge Univ Press, Cambridge, 382 pp 
Greene DF, Johnson EA (1996) Wind dispersal of seeds from forest into a clearing. Ecology 77:595-609

Greene DF, Johnson EA (1997) Secondary dispersal of tree seeds on snow. J Ecol 85:329-340

Hampe A (2004a) Bioclimate envelope models: what they detect and what they hide. Glob Ecol Biogeogr 13:469-471

Hampe A (2004b) Extensive hydrochory uncouples spatiotemporal patterns of seed fall and seedling recruitment in a bird-dispersed riparian tree. J Ecol 92:797-807

Hampe A, Petit RJ (2005) Conserving biodiversity under climate changing: the rear edge matters. Ecol Lett 8:461-467

Holm S-O (1994) Reproductive patterns of Betula pendula and B. pubescens along a regional altitudinal gradient in northern Sweden. Ecography 17:60-72

Houle G (1998) Seed dispersal and seedling recruitment of Betula alleghaniensis: spatial inconsistence in time. Ecology 79:807-818

Houle G (1999) Mast seeding in Abies balsamea, Acer sacharum and Betula alleghaniensis in an old growth, cold temperate forest of north-eastern North America. J Ecol 87:413-422

Kinnaird JW (1974) Effect of site conditions on the regeneration of birch (Betula pendula Roth and B. pubescens Ehrh.). J Ecol 62:467-472

Kullman L (1986) Demography of Betula pubescens ssp. tortuosa sown in contrasting habitats close to the birch tree-limit in Central Sweden. Vegetatio 65:13-20

Laskurain NA, Olano JM, Herrera J, Loidi J (2002) Patrón espacial de la cubierta arbórea de un abedular: estudio preliminar. Naturzale 17:145-162

Laskurain NA, Escudero A, Loidi J, Olano JM (2003) Emergencia y supervivencia de especies arbóreas en un abedular-hayedo en el Parque Natural de Urkiola (País Vasco). VII Congreso Nacional de la AEET, Barcelona

Matlack GR (1989) Secondary dispersal of seed across snow of Betula lenta, a gap colonizing tree species. J Ecol 77:853-869

Matlack GR (1992) Influence of fruit size and weight on wind dispersal in Betula lenta, a gap colonizing tree species. Am Midl Nat 128:30-39

McCarthy JJ, Canziani OZ, Leary NA, Dokken DJ, White KS (2001) Climate Change 2001: impacts, adaptation and vulnerability. Contributions of Working Group II to the Third Assessment Report of the International Panel of Global Change. Cambridge University Press, Cambridge

Mendoza I, Zamora R, Castro J (2009) A seeding experiment for testing tree-community recruitment under variable environments: implications for forest regeneration and conservation in Mediterranean habitats. Biol Conserv 142:1491-1499

Miles J, Kinnaird JW (1979) The establishment and regeneration of birch, juniper and Scots pine in the Scottish Highlands. Scot For $33: 102-119$
Molau U, Larsson EL (2000) Seed rain and seed bank along an alpine altitudinal gradient in Swedish Lapland. Can J Bot 78:728-747

Ohlemüller R, Gritti ES, Sykes MT, Thomas CD (2006) Quantifying components of risk for European woody species under climate change. Glob Chang Biol 12:1788-1799

Otto R, Krüsi BO, Delgado JD, Fernández-Palacios JM, García E, Arévalo JR (2010) Regeneration niche of the Canarian juniper: the role of adults, shrubs and environmental conditions Ann. For Sci 67:709-717

Pulido F, Sanz R, Abel D, Gil A, González-Bornay G, Hernández A, Moreno G, Pérez JJ, Vázquez FM (2007) Los bosques de Extremadura: evolución, ecología y conservación. Junta de Extremadura, Mérida, $305 \mathrm{pp}$

Pulido F, Valladares F, Calleja JA, Moreno G, González G (2008) Tertiary relict trees in a Mediterranean climate: abiotic constraints on persistence of Prunus lusitanica at the eroding edge of its range. J Biogeogr 35:1425-1435

Rangel TFLVB, Diniz-Filho JAF, Bini LM (2006) Towards an integrated computational tool for spatial analysis in macroecology and biogeography. Glob Ecol Biogeogr 15:321-327

Reyes O, Casal M (2000) Variación en la producción, capacidad germinativa y dispersión de semillas de Betula pendula Roth. en Galicia. Rev Acad Gal Cien 21:121-136

Reyes O, Casal M (2003) Estrategia reproductiva del abedul frente a los incendios forestales en Galicia. Cuad Soc Esp Cien For 15:171-176

Sanz R, Pulido F, Nogués-Bravo D (2009) Predicting mechanisms across scales: amplified effects of abiotic constraints in the recruitment of yew Taxus baccata. Ecography 32:1-8

Sarvas R (1948) A research on the regeneration of birch in South Finland. Comm Inst For Fenn 40:1-35

Skoglund J, Verwijst T (1989) Age structure of woody species populations in relation to seed rain, germination and establishment along the river Dalälven, Sweden. Vegetatio 82:25-34

Svenning JC, Skov F (2007) Could the tree diversity pattern in Europe be generated by postglacial dispersal limitation? Ecol Lett 10:453-460

Truong C, Palmé AE, Felber F (2007) Recent invasion of the mountain birch Betula pubescens ssp. tortuosa above the treeline due to climate change: genetic and ecological study in northern Sweden. J Evol Biol 20:369-380

Tutin TG, Burge NA, Chater AO, Edmondsod JR, Heywood VH, Moore DM, Valentine DH, Walters SM, Webb BA (1993) Flora europaea. Volume 1. Psilotaceae to Platanaceae. Cambridge University Press, Cambridge

Van der Pijl L (1982) Principles of dispersal in higher plants. Springer, Berlin, $215 \mathrm{pp}$ 